\title{
Raul Pompeia, Abílio César Borges e a escola brasileira no século XIX 1*
}

Regina Zilberman ${ }^{2}$

RESUMO: As referências à participação de Abílio César Borges na educação brasileira datam da década de 1860. Autor de livros didáticos, ele foi bastante popular na Bahia, sua terra natal, depois no Rio de Janeiro. Festejado pelos poetas Castro Alves e Rozendo Moniz Barreto, foi criticado por Raul Pompeia no romance $O$ Ateneu. A crítica de Pompeia não visava atingir apenas o educador baiano, mas o sistema escolar brasileiro de seu tempo.

PALAVRAS-CHAVE: Raul Pompeia, $O$ Ateneu, Abílio César Borges, educação brasileira.

ABSTRACT: References to the impact of Abílio César Borges in the Brazilian education go back to the decade of 1860. Author of several school books, he was very popular in his homeland Bahia, and then in Rio de Janeiro. Celebrated by the poets Castro Alves and Rozendo Moniz Barreto in his early years, he was criticized by Raul Pompeia in the novel O Ateneu. Pompeia’s criticism aimed not only Abílio César Borges, but mainly the Brazilian education system.

KEYWORDS: Raul Pompeia, O Ateneu, Abílio César Borges, Brazilian education system.

\begin{abstract}
Mas não é só da instrução propriamente dita que se deve ocupar a escola: tem ela outra missão mais séria, mais alta, mais nobre, e direi até mais santa. É a que entende com o caráter do menino, isto é, com a direção de suas faculdades intelectuais e morais; a saber, a que alumia a consciência da família, da pátria e da humanidade; a que, em suma, ilustra a razão e dirige os afetos.
\end{abstract}

(Abílio César Borges)

O primeiro fato memorável da vida do escritor Raul Pompeia (1863-1895) parece ter ocorrido em 1873, quando sua família se transferiu do interior da Província do Rio de Janeiro para a Corte. No mesmo ano, o menino, nascido em 1863 e agora com dez anos, é matriculado na escola de Abílio César Borges (1824-1891). Esse professor já tinha feito notável carreira pedagógica na Bahia, era um conhecido autor de livros didáticos e, no mesmo ano de 1873, funda na Corte, conforme Max Fleiuss (1868-1943), "o Colégio Abílio, em edifício majestoso, bem arejado e iluminado, com todos os requisitos da higiene escolar" (FLEIUSS, 1924, p. 428).

As atividades educacionais de Abílio César Borges haviam começado na Bahia, sua terra natal. Conforme Max Fleiuss, "em 1850, seguiu o dr. Abílio Borges para o interior da sua província natal, onde, cedendo afinal a uma irresistível vocação inata, fundou um colégio, na vila, hoje cidade da Barra, ao mesmo tempo em que ali instalava também, como médico, um hospital, nos sertões da Bahia" (FLEIUSS, 1924, p. 425). Em 1856, foi nomeado Diretor Geral da Instrução Primária e Secundária, cargo que, nas palavras de Fleiuss, "exerceu durante dois anos, salientando-se pela atividade febril e pelo singular tino ad-

${ }^{1 *}$ Este artigo desenvolve questões expostas originalmente em “Um assunto entre Pompéia e Abílio", publicado em Remate de Males - Revista do Departamento de Teoria Literária, do Instituto de Estudos da Linguagem, Universidade Estadual de Campinas/UNICAMP.

${ }^{2}$ Professora doutora do Instituto de Letras da Universidade Federal do Rio Grande do Sul - Porto Alegre. Contato: reginaz@portoweb.com.br 
ministrativo" (FLEIUSS, 1924, p. 425). Primitivo Moacyr transcreve parte do relatório que o futuro Barão de Macaúbas redigiu no ano de sua nomeação, em que denuncia uma das principais carências da educação brasileira - a falta de bons compêndios didáticos:

Depois de um excelente professorado, de boas casas para escolas, abundância e frequência de alunos, faltam-nos ainda bons compêndios para o uso escolar e livros escolhidos, manuais práticos de todos os ramos de indústria para o povo; e também um jornal de instrução pública para os professores e comissários... A uniformidade dos livros de leitura tem a inestimável utilidade de espalhar pelo povo a igualdade de conhecimentos, igualdade nos hábitos de ordem e mais que tudo a unidade moral de que tanto carece a nossa sociedade. Não os possuímos; e o mais azado meio de alcançá-los parece ser o fornecimento de prêmios vantajosos aos autores de compêndios; e os melhores e mais resumidos manuais práticos de instrução, e de ciências e artes aplicadas, quer originais, quer traduzidos, segundo uns programa formulado pelo Conselho de instrução pública. (MOACYR, 1939, p. 102)

Dois anos depois, Abílio César Borges inaugura sua trajetória de diretor e proprietário de escolas, fundando "um grande estabelecimento particular de ensino, o Ginásio Baiano, que gozou sempre da melhor reputação como um instituto-modelo no gênero, onde livremente aplicou, com os melhores resultados, os mais modernos métodos didáticos" (FLEIUSS, 1924, p. 426). Na década de 1860, Abílio começa a publicar obras destinadas ao ensino, os livros de leitura cuja carência ele mesmo denunciara. Como autor de livros didáticos, propaga seu nome por todo o país, pavimentando o caminho que o levará ao Rio de Janeiro e à fundação do Colégio onde, e isto no mesmo ano de 1873, estudará o jovem Raul Pompeia, quando sua família faz o mesmo percurso, do interior da Província para a Corte.

Essa trajetória é resumida pelo narrador de $O$ Ateneu, o romance em que Pompeia traduz suas experiências educacionais na condição de aluno de prestigiada escola carioca:

O Dr. Aristarco Argolo de Ramos, da conhecida família do Visconde de Ramos, do Norte, enchia o Império com o seu renome de pedagogo. Eram boletins de propaganda pelas províncias, conferências em diversos pontos da cidade, a pedidos, à sustância, atochando a imprensa dos lugarejos, caixões, sobretudo, de livros elementares, fabricados às pressas com o ofegante e esbaforido concurso de professores prudentemente anônimos, caixões e mais caixões de volumes cartonados em Leipzig, inundando as escolas públicas de toda parte com a sua invasão de capas azuis, róseas, amarelas, em que o nome de Aristarco, inteiro e sonoro, oferecia-se ao pasmo venerador dos esfaimados de alfabeto dos confins da pátria. Os lugares que os não procuravam eram um belo dia surpreendidos pela enchente, gratuita, espontânea, irresistível! E não havia senão aceitar a farinha daquela marca para o pão do espírito. E engordavam as letras, à força, daquele pão. Um benemérito. Não admira que em dias de gala, íntima ou nacional, festas do colégio ou recepções da coroa, o largo peito do grande educador desaparecesse sob 
constelações de pedraria, opulentando a nobreza de todos os honoríficos de berloques. (POMPEIA, 1981, p. 32-33)

O quadro desenhado pelo escritor pode parecer exagerado. Desmente a impressão o testemunho de José Ricardo Pires de Almeida (1843-1913), pesquisador da história da educação brasileira e contemporâneo tanto de Abílio César Borges, quanto de Raul Pompeia, que observa, em obra originalmente datada de 1889:

Entre as gramáticas elementares, fala-se muito de uma conhecida pelo nome de Gramática de Abílio (Barão de Macaúbas, famoso educador, proprietário-diretor de dois estabelecimentos de instrução primária e secundária, um, no Rio de Janeiro e outro, em Barbacena, Minas Gerais). Ele publicou sob seu nome, Abílio César Borges, uma multidão de livros escolares que adquiriram uma justificada reputação e a grande maioria a adotou nos principais estabelecimentos de instrução. O autor mandou imprimir edições consideráveis destes livros, que têm contribuído poderosamente para a difusão da instrução, e ofereceu, generosamente, milhares de exemplares, seja às municipalidades pobres, seja às associações que têm escolas a seu cargo. (ALMEIDA, 1989, p. 159)

Ainda na Bahia, Abílio César Borges parece ter sido festejado, a se acreditar nos versos que um dos alunos da escola que dirigia, Antônio de Castro Alves Júnior (1847-1871), o futuro poeta dos escravos, lhe dedicou por ocasião do aniversário de seu professor:

\author{
Grato sempre à mocidade, \\ Belo dia, hás de raiar; \\ Sempre ela muito contente \\ Mil flores te há de ofertar! \\ Sempre em ti se entregará \\ Ao prazer com expansão; \\ Mil cultos render-te-á \\ Nos altares d'afeição. \\ Pois em ti, sublime dia, \\ Do alto dos céus baixou \\ $\mathrm{O}$ anjo, que à mocidade \\ Dos rigores libertou. \\ Baixou este grande homem, \\ Que tanto anima a instrução, \\ Estimulando co'amor \\ O infantil coração. (ALVES, 1977, p. 565)
}

Esse poema, datado de 1860 e intitulado "Ao Natalício de meu Diretor, o Ilmo. Sr. Doutor Abílio César Borges", soma 42 versos, divididos em três partes, das quais a primeira é citada aqui. Castro Alves não se limitou apenas a essa celebração, pois dedicou ao mestre alguns sonetos, dentre os quais o que se reproduz a seguir: 


\begin{abstract}
Mancebos! De mil louros triunfantes
Adornai o Moisés da mocidade,

$\mathrm{O}$ anjo que nos guia da verdade

Pelos doces caminhos sempre ovantes.

Coroai de grinaldas verdejantes

Quem rompeu para a Pátria nova idade,

Guiando pelas leis sãs da amizade

Os moços do progresso sempre amantes.

Vê, Brasil, este filho que o teu nome

Sobre o mapa dos povos ilustrados

Descreve qual o forte de Vendome.

Conhece que os Andradas e os Machados,

Que inda vivem nas asas do renome,

Não morrem nestes céus abençoados! (ALVES, 1977, p. 574)
\end{abstract}

Reconhecem-se nessas estrofes os traços do futuro condoreiro, ao comparar o diretor da escola a Moisés, líder a guiar a mocidade para além de um mar de intranquilidades. Mas não apenas Castro Alves dedicou versos ao eminente educador. Seu conterrâneo Rozendo Moniz Barreto (1845-1897), em Cantos d'aurora, de 1868, apresenta o poema "O livro e o século", obra "recitada no Ginásio Baiano, depois da distribuição dos prêmios aos alunos do mesmo colégio e oferecida a seu benemérito diretor, o Ilmo. Sr. Dr. Abílio César Borges" (BARRETO, 1868, p. 404).

Rozendo Moniz Barreto era dois anos mais velho que Castro Alves, portanto, os dois moços podem ter sido colegas enquanto frequentavam a prestigiada escola baiana. $\mathrm{O}$ poema dedicado ao ilustre educador, por sua vez, antecipa "O livro e a América", com que Castro Alves abre as Espumas flutuantes, lançadas em 1870. Reconhecem-se alguns pontos em comum entre os dois textos: o retrospecto histórico até chegar à façanha de Gutenberg; o elogio ao produto do inventor alemão, que Rozendo assim enuncia:

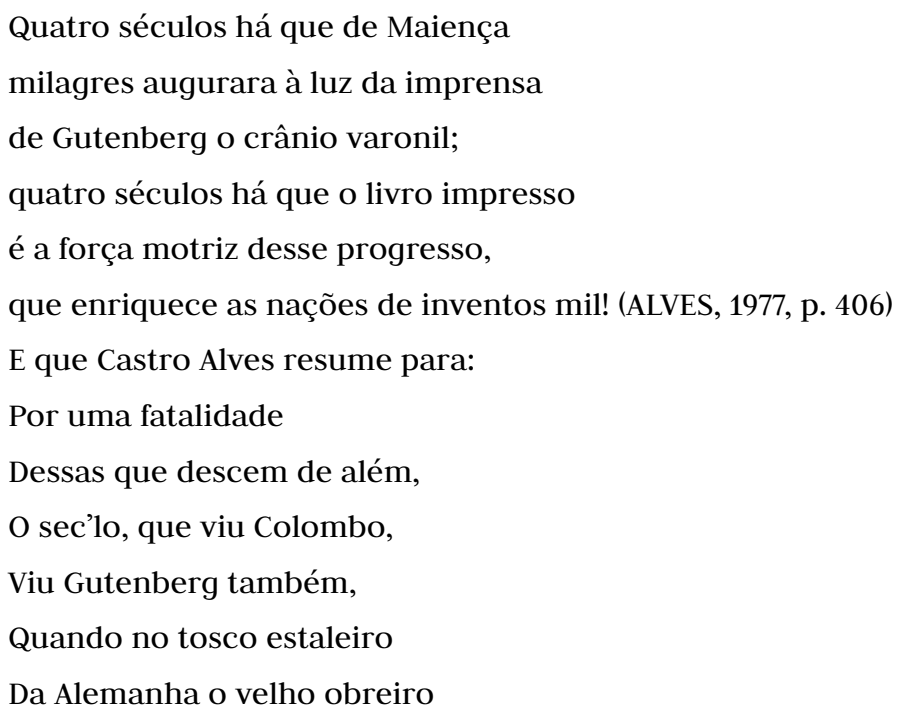


Seguem-se nos dois poemas o elogio do livro, que Rozendo complementa com loas mútuas tanto ao objeto de seus versos, quanto ao diretor da escola, colocados no mesmo plano, conforme indica a última estrofe, após a qual se apontam o local e a data de sua produção:

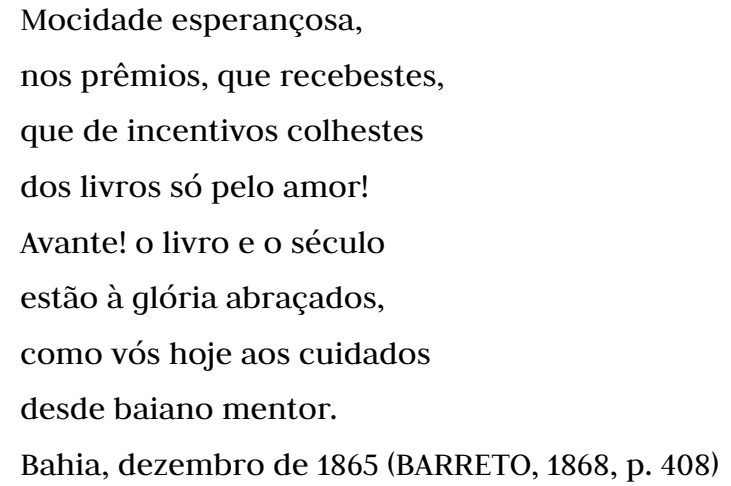

A proximidade temática entre os poemas dos dois escritores baianos, que, além de conterrâneos, eram contemporâneos, amigos e eventualmente ex-colegas, teria sido fruto da prática pedagógica de Abílio? Provavelmente não, já que manifestações de louvor ao livro aparentemente não eram incomuns, bastando lembrar crônica de teor similar, redigida, em 1859, pelo jovem Machado de Assis (1958, p. 963-965). De todo modo, tantos encômios não foram suficientes para manter em sua terra natal o professor, que se transferiu para o Rio de Janeiro.

Na Corte, implantou novas instituições, como a já mencionada, nascida em 1873 e refundada em 1883, quando passou a se chamar Novo Colégio Abílio. Era também proprietário, conforme aponta José Ricardo Pires de Almeida, de uma escola instalada na cidade de Barbacena, Minas Gerais, nascida em 3 de fevereiro de 1881, conforme as datas fornecidas por Max Fleiuss (1924, p. 430).

Certamente não era o estabelecimento que Rubião, protagonista do Quincas Borba, de Machado de Assis, regera, já que a ação daquele romance passa-se entre meados de 1860 e meados de 1870; mas talvez a cidade onde residia o ex-"simples professor"3 (ASSIS, 1959, p. 11-12) tivesse sido escolhida pelo ficcionista por sugestão (consciente ou não) da trajetória do ilustre docente baiano.

Raul Pompeia, por sua vez, fez outros estudos: em 1879, transferiu-se para o Imperial Colégio de Pedro II, onde cursou o sexto ano e participou da instalação do Grêmio Literário Amor ao Progresso, responsável pela edição da revista As Letras, cuja Comissão Redatora contou com o futuro romancista (COUTINHO, 1981). É desse período que data igualmente a redação de Uma tragédia no Amazonas, seu livro de estreia.

Em 1888, ano em que $O$ Ateneu, crônica de saudades, é publicado em folhetim na Gazeta de Notícias e, logo a seguir, em livro, Abílio César Borges era um educador res-

3 A anotação do narrador do romance indica com clareza a procedência e a atividade de Rubião, antes de herdar a fortuna de Quincas Borba e mudar-se para a Corte: “Quincas Borba tivera ali alguns parentes, mortos já agora em 1867; o último foi o tio que o deixou por herdeiro de seus bens. Rubião ficou sendo o único amigo do filósofo. Regia então uma escola de meninos, que fechou para tratar do enfermo. Antes de professor, metera ombros a algumas empresas, que foram a pique”. 
peitável, tendo-se destacado particularmente na Exposição Pedagógica de 1883, quando, conforme narra Max Fleiuss, "no salão de honra (...), em presença do imperador, a 28 de setembro e 7 de outubro de 1883, fez o Barão de Macaúbas duas notáveis conferências acerca do "Aritmômetro fracionário", de sua invenção, e sobre a "Lei nova de ensino infantil”, aplicada ao Colégio Abílio" (FLEIUSS, 1924, p. 430).

Carl von Koseritz (1830-1890), intelectual alemão radicado no Brasil e jornalista, também comenta a participação de Abílio César Borges na Exposição Pedagógica de 1883, sem externar, contudo, o mesmo entusiasmo. Identifica o pendor mercantilista do educador, faceta igualmente destacada por Pompeia em $O$ Ateneu, além de seu exibicionismo e preocupação em ascender os graus hierárquicos da nobreza brasileira à época da monarquia:

A representação brasileira está distribuída em duas salas. Uma delas foi cheia pelo Colégio Abílio com todos os objetos possíveis que se relacionam com o ensino. Ali se vê, como propriedade deste colégio, quase tudo que nas outras salas é exposto por países diferentes, e causam uma bela impressão as instalações de ginásticas e esgrima do colégio. O Dr. Abílio, (aliás Barão de Macaúbas), sabe fazer valer a sua mercadoria, e não cochilou. Não menos grandioso, e talvez mesmo mais importante é o mostruário do Colégio Meneses Vieira, que segue completamente o sistema alemão, e que por isto é o único a exibir, em toda a exposição, uma bandeira alemã ao lado da brasileira. Este colégio apresenta excelentes instrumentos de ensino e de ginástica, coleções etc., tudo de origem alemã e também todos os objetos usados no chamado "Jardim da Infância". Um busto de Froebel orna o recinto e me interessou particularmente. Meneses Vieira será feito barão, como Abílio? Não o creio, pois ele não sabe se exibir tão bem como o outro, que desta vez passará seguramente a visconde. No total a impressão que retirei da exposição foi muito satisfatória e eu espero que ela exerça influência favorável sobre a instrução local. Os professores podem aprender muito ali, e terão à vista elementos de que não faziam a menor idéia. O pensamento foi feliz. (KOSERITZ, 1972, p. 124)

Os livros didáticos assinados por Abílio César Borges foram continuamente reeditados, e mesmo a proclamação da República não impediu o velho Barão de Macaúbas de continuar a oferecer seu conhecido material didático, agora adaptado aos novos tempos. Escreve ele no prólogo da sexagésima quinta edição de seu Terceiro livro de leitura, de 1890:

Tendo-se esgotada a sexagésima-quarta edição deste livro, justamente quando foi proclamada a República dos Estados Unidos do Brasil, tratei logo de reformá-lo para a presente edição, pondo-o em harmonia com a nova organização social, e tornando-o ao mesmo tempo mais interessante e mais apropriado ao ensino da geração, que desponta, e portanto mais útil.

É assim que suprimi o longo artigo - Constituição do império; - mudei a denominação de províncias para a de estados, a de município neutro para a de distrito federal, etc. (BORGES, 1890, grifos do autor) 
Essas palavras do prólogo parecem dar razão ao Machado de Assis de Esaú e Jacó, obra que, publicada em 1904, situa a ação narrada na passagem do Império para a República. Lá, o Conselheiro Aires, autor dos cadernos que dão origem ao romance, tranquiliza o assustado Santos, banqueiro e, também ele, barão, que teme as mudanças a serem impostas pelo novo regime, com o seguinte comentário:

Aires quis aquietar-lhe o coração. Nada se mudaria; o regímen, sim, era possível, mas também se muda de roupa sem trocar de pele. (ASSIS, 1959, p. 259)

Porém, o Abílio da vida real parece dar razão mesmo ao Abílio ficcional, vale dizer, ao Aristarco de $O$ Ateneu. Não que Raul Pompeia, nos seus textos, tenha-se restringido ao exame da escola do Barão de Macaúbas. Afinal, a se julgar pelo necrológio que publicou em 1891, por ocasião da morte de seu antigo professor, ele admirava o velho mestre:

Sábado deixou de existir o Dr. Abílio César Borges, Barão de Macaúbas, que foi com justiça o mais considerado dos educadores da mocidade brasileira.

Cheio de entusiasmo pelas reformas liberais do ensino o Diretor do afamado Colégio Baiano e do Colégio Abílio foi um propagandista ardente e eficacíssimo do melhoramento das condições do ensino primário e secundário; e os consideráveis estabelecimentos que por longos anos, sob a direção dos seus ativos e zelosos cuidados distribuíram educação e ensino a um sem-número de rapazes, poderão em todo o tempo ser admirados como modelos e os mais perfeitos que na melindrosa espécie pedagógica dos internatos se conseguiria instituir.

Significando uma fecunda existência de trabalhos e dedicação pela causa sagrada da educação popular, seu nome será sempre lembrado em grata e luminosa recordação. (POMPEIA, 1983, p. 168-169)

Além disso, ainda em 1882, também por meio de uma crônica, ele atacou o Colégio de Pedro II, acusando seus professores de se curvar à autoridade: "Sei que aquilo não é uma corporação de fortes, mas um grupo de caracteres de barbatanas, tão fáceis de curvar-se, como apressados de retesar-se, aliados do peso que os vergava...” (POMPEIA, 1982a, p. 51).

Dirige sua crítica especialmente ao titular do ensino de grego, o Dr. Schieffer, que "ignora a matéria que ensina" e depende de um mau compêndio. Na descrição do professor, reconhece-se o estilo amargo e impiedoso do autor de $O$ Ateneu:

Cinge-se ao compêndio de Kuehner, que ele mesmo teve a habilidade de estragar por meio de uma tradução monstruosa, incompreensível como um hieroglifo; não dá aos discípulos a menor explicação, senão mui raramente e sobre ninharias; manda fazer umas traduções enormes da Ilíada, para a qual exige os mesmos significados dos burros franceses (...): deixando sem uma observação as belezas de que se acha estrelado o poema grego, assassinando a expressão e a harmonia dos versos com uma leitura que não conhece hemistíquios, nem pontuação, e consentindo que os pequenos sicários seus alunos, espostejem os cadáveres que ele prepara sem poder gritar-lhes (os alunos) como um poeta francês:

Essa crônica foi publicada no Jornal do Comércio, do Rio de Janeiro, em 20 de janeiro de 1891. 
Arrête, par pitié!... porque ele próprio é o primeiro assassino; mastigando uma algaravia que só um poliglota do inferno poderia perceber, apesar de ter de residência no Brasil dez vezes mais do que o tempo necessário para se aprender a falar uma língua... (POMPEIA, 1981, p. 53, grifos do autor)

Em outra crônica, de 1889, Pompeia volta a se referir ao nefando mestre, quando faz o necrológio de seu oposto, o brando professor Braune, docente também do Pedro II:

Outro morto: o Dr. João Henrique Braune, também lente do Colégio de Pedro II, em cuja cadeira de Grego lecionava ainda, com a zelosa assiduidade do seu vigor de moço e com a brilhante vantagem de seu talento.

Quem conheceu a doutrina ríspida do falecido Schiefler (sic), antecessor imediato do Dr. Braune na cadeira de Grego, e teve ocasião de apreciar a meiga doçura, o quase carinho do método de ensinar de seu substituto, sabe que amigo perdeu a mocidade com a perda deste mestre... O grande estabelecimento oficial de ensino secundário perdeu também extraordinariamente. O Dr. Braune era uma das mais justas esperanças dessa plêiade de moços, em que se contam os nomes de Capistrano de Abreu, Gama Berquó, Nerval de Gouveia, Sílvio Romero, Raja Gabaglia, ultimamente instalados nas cadeiras do Imperial Colégio para enxertar, no carrancismo daquela instituição, a coragem dos modos novos do pensamento e a liberdade dos métodos modernos, que o antigo pessoal docente, Schiefler (sic), Dragos, Halbouts, sempre detestou e repeliu... (POMPEIA, 1982, p. 281)

Esses professores poderiam facilmente participar do elenco do romance: Schieffer, Drago e Halbout comporiam ao lado do terrível professor Venâncio, enquanto que os historiadores Capistrano de Abreu (1853-1927) e Sílvio Romero (1851-1814) fariam parceria com o progressista Dr. Cláudio, que trata, em uma de suas conferências, da literatura brasileira do passado e do presente.

Pode-se supor, pois, que a matéria de $O$ Ateneu foi extraída do conjunto das experiências escolares do autor. Em outras palavras, ainda que o Colégio Abílio, sintetizado em suas práticas pedagógicas e corporificado na figura de seu Diretor, Aristarco Argolo de Ramos, tenha fornecido os motivos principais para a escrita do livro, Raul Pompeia desenha um painel em que se reconhecem os modelos predominantes de ensino no Brasil, nas últimas décadas do século XIX.

Sérgio parece tê-los vivido todos. No primeiro capítulo de $O$ Ateneu, em que o menino, com onze anos, acompanhando o pai, é apresentado ao diretor da escola, Sérgio-adulto, o narrador, recorda como fora sua educação até então. Primeiramente, ele

frequentara como externo, durante alguns meses, uma escola familiar do Caminho Novo, onde algumas senhoras inglesas, sob a direção do pai, distribuíam educação à infância como melhor lhes parecia. Entrava às nove horas timidamente, ignorando as lições com a maior regularidade, e bocejava até às duas, torcendo-me de insipidez, sobre os carcomidos bancos que o colégio comprara, de pinho e usados, lustrosos do contacto da malandragem de não sei quantas gerações de pequenos. Ao meio-dia, davam-nos pão 
com manteiga. Esta recordação gulosa é o que mais pronunciadamente me ficou dos meses de externato; (...). (POMPEIA, 1981, p. 31)

Depois, tomara "professor em domicílio" (POMPEIA, 1981, p. 31); só então o pai leva-o a uma escola, onde a aprendizagem organiza-se em disciplinas diferentes ministradas por professores especializados, seguindo-se em séries que progressivamente avançam no saber.

Eis aí os três modelos de ensino que vigoravam na educação brasileira: as escolas de uma única sala de aula e um único proprietário-professor, autoritário e incompetente, onde estudavam alunos em diferentes estágios de conhecimento. Esse tipo de escola e de professor aparece com grande frequência na literatura e no memorialismo brasileiro. O “Conto de escola”, de Machado de Assis, confirma essa presença assídua na prosa nacional, bem como na vida dos estudantes brasileiros:

Ora, foi a lembrança do último castigo que me levou naquela manhã para o colégio. Não era um menino de virtudes.

Subi a escada com cautela, para não ser ouvido do mestre, e cheguei a tempo; ele entrou na sala três ou quatro minutos depois. Entrou com o andar manso do costume, em chinelas de cordovão, com a jaqueta de brim lavada e desbotada, calça branca e tesa e grande colarinho caído. (...)

O pior que ele podia ter, para nós, era a palmatória. E essa lá estava, pendurada no portal da janela, à direita, com os seus cinco olhos do diabo. Era só levantar a mão, despendurá-la e brandi-la, com a força do costume, que não era pouca. (ASSIS, 1959, p. 209-214)

O escritor e jornalista Justiniano José da Rosa (1812-1862) fez, a pedido do imperador Pedro II (1825-1891), um exame do ensino secundário no Rio de Janeiro. Em seu relatório, não se refere à prática da violência e aos castigos corporais; porém, sua opinião não é menos favorável que a de Machado de Assis quanto à qualidade dos estabelecimentos instalados no então principal centro urbano do Brasil:

Há no Rio de Janeiro, atente e desregrada aplicação da liberdade de indústria ao ensino, uma infinidade de colégios e de escolas, de cuja existência nem é possível dar fé; multiplicam-se tais estabelecimentos por quase todas as ruas; quem quer que pode por quaisquer meios reunir meia dúzia de meninos, arvora-se em educador da mocidade, e daí tira um lucro que, embora insignificante, de sobejo compensa o seu trabalho. Casas dessa ordem são tantas que, se quisesse visitá-las, nunca poderia dar conta a V. Exa. da minha comissão, e até sem longas indagações e talvez sem o auxílio dos inspetores de quarteirão, nunca chegasse a ter uma lista exata delas.

Ocupar-me-ei primeiramente com as aulas públicas, porquanto acerca delas pouco tenho a dizer. Acham-se espalhadas pela cidade, ao alvitre do professor, em nenhuma correspondência com os seus colegas; de ninguém recebem direção comum; as lições são de manhã ou à tarde, como ao professor parece mais cômodo: o tempo é curtíssimo 
para suas explicações, especialmente nas aulas de latim; porquanto obrigado o professor a admitir, em qualquer época do ano, os alunos de qualquer idade, de qualquer grau de adiantamento, vê-se obrigado a multiplicar classes e decúrias e a dividir entre elas seus cuidados e as poucas horas das suas lições. (ROCHA, 1964, p. 117)

Professores "em domicílio" constituem igualmente uma prática documentada, conforme lembra José Veríssimo, ao se referir à educação feminina na segunda metade do século XIX:

\footnotetext{
A melhoria da instrução da mulher começou no Brasil vai por um terço de século com a criação das Escolas Normais, para formar professoras primárias. Antes disso, somente as moças de famílias abastadas recebiam alguma instrução, por via de regra deficiente e de aparato, já em casa de seus pais, com mestres particulares, que há mais de meio século têm existido no Brasil, como uma indústria lucrativa. (VERÍSSIMO, 1906, p.4)
}

Por sua vez, o ensino seriado, em escolas leigas, que o garoto Sérgio conhece quando inscrito no Ateneu, é inaugurado pelo Colégio de Pedro II, fundado em 1837. Ministrava formação tanto humanística, quanto científica, e conferia um diploma de bacharel aos jovens da elite carioca. Esse modelo de ginásio expande-se aos poucos na educação brasileira, e Abílio, quando funda sua primeira escola, na Bahia, acompanha a regra do Pedro II, que depois reintroduz no Rio de Janeiro. A diferença é que, nas escolas particulares, o diretor é o proprietário, e sua figura dominadora não contradiz o modelo autoritário que se reproduz nas salas de aula de um único dono, como as descritas antes por Justiniano José da Rocha e Machado de Assis.

Aristarco-Abílio não parece diferir muito de outros diretores autoritários, como o que José de Alencar conheceu na sua infância e que, ao contrário de Pompeia, recorda com admiração e respeito:

No ano de 1840, frequentava eu o Colégio de Instrução Elementar, estabelecido à Rua do Lavradio, n. 17, e dirigido pelo Sr. Januário Mateus Ferreira, a cuja memória eu tributo a maior veneração.

Depois daquele que é para nós meninos a encarnação de Deus e o nosso humano Criador, foi esse o primeiro homem que me incutiu respeito, em que acatei o símbolo da autoridade.

Dividia-se o diretor por todas as classes, embora tivesse cada uma seu professor especial; desse modo andava sempre ao corrente do aproveitamento de seus alunos, e trazia os mestres como os discípulos em constante inspeção. Quando, nesse revezamento de lições, que ele de propósito salteava, acontecia achar atrasada alguma classe, demorava-se com ela dias e semanas, até que obtinha adiantá-la e só então a restituía ao respectivo professor. 
Rara vez sentava-se o diretor; o mais do tempo levava a andar de um a outro lado da sala em passo moderado. Parecia inteiramente distraído da classe, para a qual nem volvia os olhos; e todavia nada lhe escapava. O aparente descuido punha em prova a atenção incessante que ele exigia dos alunos, e da qual sobretudo confiava a educação da inteligência. (ALENCAR, 1990, p. 15-18)

A diferença é que Aristarco, na sua própria opinião, enuncia um projeto modernizador para a educação, exposto por ele ao pai de Sérgio nas primeiras páginas do livro e reproduzido pelo narrador por intermédio do discurso indireto livre, forma oblíqua de desmentir, de imediato, as palavras do diretor:

Trinta anos de tentativas e resultados, esclarecendo como um farol diversas gerações agora influentes no destino do país! E as reformas futuras? Não bastava a abolição dos castigos corporais, o que já dava uma benemerência passável. Era preciso a introdução de métodos novos, supressão absoluta dos vexames de punição, modalidades aperfeiçoadas no sistema das recompensas, ajeitação dos trabalhos, de maneira que seja a escola um paraíso, adoção de normas desconhecidas cuja eficácia ele pressentia, perspicaz como as águias. Ele havia de criar... um horror, a transformação moral da sociedade. (POMPEIA, 1981, p. 48)

O diálogo com Aristarco faz-se no interior do texto, com a interferência do comentário do narrador, que julga "um horror" o propósito moralizante do ensino ministrado na escola. Mas é também réplica ao discurso do próprio Abílio, que, no Terceiro livro de leitura, advoga uma educação que forme moral e civicamente os estudantes:

Por outra, e em breves termos, deve a instrução primária ser a reunião de todas as influências morais, religiosas e sociais que, cercando o homem desde os primeiros anos, constituem a vida íntima do indivíduo, e perpetuam a vida nacional dos povos. (BORGES, 1890)

É ao projeto de “abolição dos castigos corporais" que Raul Pompeia confere maior atenção. Que a questão preocupava outros pedagogos brasileiros,indica-o o fato de Apolinário Porto Alegre (1844-1904), professor, intelectual e escritor sul-rio-grandense, fundar, em 1876, o Instituto Brasileiro com intenções similares às que Raul Pompeia atribui a Aristarco Argolo de Ramos:

Ao criar o Instituto Brasileiro, em 1876, (...), audaciosamente Apolinário atacava a educação tradicional, reformando os programas de estudo, abolindo o castigo corporal, meio tirânico que aviltava os mestres e os discípulos, pois o estudo não se impõe, ensina-se. (FLORES, 1994, p. 135)

Abílio César Borges também condena meios violentos de aprendizagem, simbolizados pelos “cinco olhos do diabo", conforme a imagem, reproduzida antes, de Machado de Assis: “E sempre a perspectiva medonha da palmatória a amargurar-lhe os cândidos e inocentes dias da infância, e a fazer-lhe odioso o mestre, a escola e o estudo!" (BORGES, 1890, grifo do autor). 
O problema é que a violência é soberana no âmbito do colégio administrado por Aristarco. Tanto o diretor reproduz o método de vigilância recordado por José de Alencar,

A sala geral de estudo tinha inúmeras portas. Aristarco fazia aparições de súbito a qualquer das portas, nos momentos em que menos se podia contar com ele.

Levava as aparições às aulas, surpreendendo professores e discípulos. Por meio deste processo de vigilância de inopinados, mantinha no estabelecimento por toda parte o risco perpétuo do flagrante como uma atmosfera de susto. (POMPEIA, 1981, p. 95)

quanto impera no Ateneu a cafua, "asilo das trevas e do soluço" (POMPEIA, 1981, p. 95), bem como a leitura pública, durante as refeições, dos delitos cometidos por professores e estudantes em sala de aula:

Um livro de lembranças comprido e grosso, capa de couro, rótulo vermelho na capa, ângulos do mesmo sangue. Na véspera cada professor, na ordem do horário, deixava ali a observação relativa à diligência dos seus discípulos. Era o nosso jornalismo. (...) O temível noticiário, redigido ao sabor da justiça suspeita de professores, muitas vezes despedidos por violentos, ignorantes, odiosos, imorais, erigia-se em censura irremissível de reputações. O julgador podia ser posto fora por uma evidenciação concludente dos seus defeitos; a difamação estampada era irrevogável. (POMPEIA, 1981, p. 95)

O efeito, contudo, é aquele visado por Abílio César Borges e pelos educadores de seu tempo: o exercício da autoridade conduz à aprendizagem da obediência. A sociedade é hierarquizada, e os subalternos devem aceitar a ordem e a primazia dos superiores; por causa disso, a escola adota a mesma organização, podendo apresentar-se como um microcosmo que prepara a criança e o adolescente para enfrentar a vida fora de seus muros.

Abílio César Borges advoga a ideia em seu livro, fundando aí seu projeto educacional. É como também justifica a necessidade de haver escolas e estas se apresentarem como lugar preferencial de aprendizagem, substituindo o lar e fazendo a mediação entre a família privada e a sociedade, o universo público:

O colégio, meus amigos, é um mundozinho: é, a muitos respeitos, uma miniatura da grande sociedade, em que tereis de viver, ficardes homens.

Como no grande mundo ou na grande sociedade, há no colégio um chefe e autoridades superiores e inferiores, às quais deveis obediência e respeito.

Na sociedade propriamente dita há chefes dos Estados, chefes e delegados de polícia, ministros do supremo tribunal de justiça, desembargadores, juízes de direito, juízes municipais e de órfãos, juízes de paz, inspetores de quarteirão, comandantes militares e soldados, aos quais todos, nas convenientes proporções, deveis obediência e respeito, como guardas que são das leis e garantias dos direitos dos cidadãos.

Pois no colégio tendes também diretor, vice-diretor, inspetores, professores, monitores e decuriões, aos quais todos deveis igualmente obediência e respeito; pois representam todos a lei do colégio, são garantias da ordem e têm, cada um no seu tanto, a auto- 
ridade que lhes vem do diretor, que é supremo legislador e ao mesmo tempo supremo juiz do estabelecimento, como o é cada chefe de família dentro de sua casa.

E, do mesmo modo que na sociedade geral é réu de grave crime todo aquele que desobedece a qualquer autoridade, também na pequena sociedade colegial é réu de grave crime o menino, que desobedece a qualquer dos seus superiores.

Também é na escola, ou no colégio, que o menino aprende a virtude da obediência, tão necessária para se ser feliz na vida social. (BORGES, 1890)

Não por outra razão o Dr. Cláudio, professor que representa a ala esclarecida na instituição dirigida por Aristarco, faz uma conferência em que justifica o papel dos internatos: são eles que efetivamente preparam o jovem para enfrentar o mundo. Não porque inculquem valores positivos ou saudáveis, mas porque constituem a escola da corrupção:

\footnotetext{
Discutiu a questão do internato. Divergia do parecer vulgar, que o condena.

É uma organização imperfeita, aprendizagem de corrupção, ocasião de contactos com indivíduos de toda origem? O mestre é a tirania, a injustiça, o terror? O merecimento não tem cotação, cobrejam as linhas sinuosas da indignidade, aprova-se a espionagem, a adulação, a humilhação, campeia a intriga, a maledicência, a calúnia, oprimem os prediletos do favoritismo, oprimem os maiores, os mais fortes, abundam as seduções perversas, triunfam as audácias dos nulos? a reclusão exacerba as tendências ingênitas?

Tanto melhor: é a escola da sociedade. (POMPEIA, 1981, p. 234)
}

Como que parodiando as palavras de Abílio, o Dr. Cláudio afirma: "Ensaiados no microcosmo do internato, não há mais surpresas no grande muro lá fora.” (POMPEIA, 1981, p. 235). E conclui:

O internato com a soma dos defeitos possíveis é o ensino prático da virtude, e a aprendizagem do ferreiro à forja, habilitação do lutador na luta. Os débeis sacrificam-se; não prevalecem. Os ginásios não são para os privilegiados da saúde. O reumatismo deve ser um péssimo acrobata. Erro grave combater o internato. (POMPEIA, 1981, p. 235)

O Dr. Cláudio dá razão ao pai de Sérgio, que, na primeira linha do romance, diz dramaticamente para o filho: "Vais encontrar o mundo, disse-me meu pai, à porta do Ateneu. Coragem para a luta." (POMPEIA, 1981, p. 29). O mundo é o universo dos Abílios, contra quem Pompeia se digladiou por longos anos, sem chegar a sair-se vencedor.

\section{Referências Bibliográficas}

ALENCAR, José de. Como e porque sou romancista. Campinas: Pontes, 1990.

ALMEIDA, José Ricardo Pires de. História da instrução pública no Brasil, 1500 a 1889. Trad. de Antônio Chizzotti. São Paulo: EDUC; Brasília: INEP, 1989.

ALVES, Antônio de Castro. Obra completa. Edição comemorativa do sesquicentenário. Organização, fixação de texto e notas de Eugênio Gomes. Rio de Janeiro: Nova Aguilar, 1977. 
. O livro e a América. In: Poesias completas de Castro Alves. Rio de Janeiro: Tecnoprint, s. d.

ASSIS, Machado de. O jornal e o livro. In: Obra completa. Rio de Janeiro: Aguilar, 1958. V. 3.

. Quincas Borba. São Paulo: Mérito, 1959.

Esaú e Jacó. São Paulo: Mérito, 1959.

Várias histórias. São Paulo: Mérito, 1959.

BARRETO, Rozendo Moniz. O livro e o século. In: Cantos d'aurora. Versos. Rio de Janeiro: Eduardo \& Henrique Laemmert, 1868.

BORGES, Abílio César (Barão de Macaúbas). Terceiro Livro de Leitura para uso das escolas brasileiras. Nova edição reformada e melhorada. Rio de Janeiro: Francisco Alves, s. d. [1890].

COUTINHO, Afrânio. Introdução geral. In: Pompeia, Raul. Novelas. Rio de Janeiro: Civlização Brasileira; OLAC; FENAME, 1981.

FLEIUSS, Max. Sessão especial, comemorativa do centenário natalício do Barão de Macaúbas. Revista Trimestral. Rio de Janeiro: Instituto Histórico e Geográfico Brasileiro 96 (150): 420 - 434, 1924.

Flores. Moacyr. Apolinário Porto Alegre. O professor e o político. In: Flores, Hilda A. Hübner (Org.). Vidas e costumes. Porto Alegre: Martins Livreiro; Nova Dimensão, 1994. KOSERITZ, Carl von. Imagens do Brasil. Trad., pref. e notas de Afonso Arinos de Melo Franco. São Paulo: Martins; EDUSP, 1972.

MOACYR, Primitivo. A instrução e as Províncias. (Subsídios para a história da educação no Brasil). 1835-1889. V. 2. São Paulo: Nacional, 1939.

POMPEIA, Raul. O Ateneu. Rio de Janeiro: Civilização Brasileira; OLAC; FENAME, 1981. . Crônicas. Rio de Janeiro: Civilização Brasileira; OLAC; FENAME, 1982. V. 1. Crônicas. Rio De Janeiro: Civilização Brasileira; OLAC; FENAME, 1983. V. IV. . Colégio de Pedro II. In: . Escritos políticos. Rio de Janeiro: Civilização Brasileira; OLAC; FENAME, 1982a.

ROCHA, Justiniano José da. Relatório sobre o ensino secundário no Rio de Janeiro. Exposição sobre o estado das aulas públicas de instrução secundária, e dos colégios e escolas particulares da capital do Império. Reproduzido em: CARDIM, Elmano. Justiniano José da Rocha. São Paulo: Nacional, 1964 (Brasiliana, v. 318).

VERÍSSIMO, José. A educação nacional. 2. ed. aumentada. Rio de Janeiro: Francisco Alves, 1906.

ARTIGO RECEBIDO EN: 11 ago. 2012

ArTigo ACEITO EM: 25 set. 2012

REFERÊNCIA ELETRÔNICA: ZILBERMAn, Regina. Raul Pompeia, Abílio César Borges e a escola brasileira no século XIX. Revista Criação \& Crítica, n. 9, p. 38-51, nov. 2012. Disponível em: <http://www.revistas.usp. $\mathrm{br} /$ criacaoecritica>. Acesso em dd mmm aaaa. 